\title{
PENTINGNYA PENDIDIKAN KARAKTER
}

\author{
Stephanus Ngamanken \\ Character Building Development Center, BINUS University \\ Jln. Kemanggisan Ilir III No. 45, Kemanggisan - Palmerah, Jakarta 11480 \\ stephanus_ngamanken@yahoo.com
}

\begin{abstract}
A study about character building was conducted to better understand the impact of character building for individual, family and community. This study used grounded research method. Individuals who have good or bad behaviors are affected by past experience in relation to the character building they received. A happy family or a broken-home family is also influenced by past experience of each member of the family. Moreover, the success or failure of a social organization in the society, in this case was a country, is also determined by the character building from the members of the organization. Finally, study concluded that character building is very important in achieving the happiness of individuals, family and society/country.
\end{abstract}

Keywords: individuals, family, society, character building

\begin{abstract}
ABSTRAK
Penelitian tentang pendidikan karakter dilakukan untuk lebih memahami dampak pendidikan karakter bagi individu, keluarga, dan masyarakat. Metode yang digunakan dalam penelitian ini adalah grounded research. Individu yang berperilaku baik atau buruk sangat dipengaruhi oleh pengalaman masa lalu dalam kaitannya dengan pendidikan karakter yang diterimanya. Sebuah keluarga bahagia atau keluarga yang berantakan juga dipengaruhi oleh pengalaman masa lalu masing-masing anggota keluarga tersebut. Lebih lanjut, keberhasilan atau kegagalan sebuah organisasi sosial di masyarakat, dalam hal ini adalah negara, juga ditentukan oleh pendidikan karakter para anggota organisasi tersebut. Penelitian menyimpulkan bahwa pendidikan karakter sangat penting dalam pencapaian kebahagiaan individu, keluarga, dan masyarakat/negara.
\end{abstract}

Kata kunci: individu, keluarga, masyarakat, pendidikan karakter 


\section{PENDAHULUAN}

Pendidikan Karakter sudah diwacanakan sejak abad ke-8 sebelum Masehi oleh Homeros. Koesoema (2007:15) mengatakan: "Pendidikan karakter dalam masyarakat Yunani Kuno, khususnya pada zaman Homeros, lebih menekankan pertumbuhan individu secara utuh dengan cara mengembangkan potensi dalam diri individu... yaitu dimensi fisik dan dimensi moral.” Pendidikan Karakter idealisme homerian yang aristokratis individual tersebut berubah menjadi idealisme kepahlawanan yang bersifat kolektif pada zaman Spartan sesuai ideologi yang dipromosikan Tirteo. Semangat cinta tanah air menurut Tirteo senantiasa menjadi jiwa setiap warga negara. Cinta tanah air dalam perkembangannya (Koesoema, 2007) tidak hanya ciri pendidikan karakter ala Sparta. Nilai-nilai heroisme, yang mengatasi kepentingan pribadi yang memuncak dalam semangat pengorbanan, memiliki nilai transendental berupa kebaikan bagi komunitas, termasuk negara. Nilai pengabdian dan cinta tanah air ini ditiru juga oleh Athena, dengan memberikan penghormatan kepada warganya yang gugur di medan perang. Saat ini di berbagai negara, pendidikan karakter ala Sparta merupakan kebangkitan kebangsaan yang patriot.

Di dalam perspektif cinta tanah air sebagai ciri pendidikan karakter, presiden Soekarno pernah memberi gagasan tentang Trisakti (Esthu, 2010). Ia mengatakan bahwa pendidikan karakter diperlukan agar bangsa Indonesia berkembang seimbang antara pengembangan material dengan pengembangan spiritual, seimbang antara pendidikan untuk karier dengan pendidikan untuk karakter. Trisakti yang digagas Soekarno pasca kemerdekaan itu merupakan sebuah proses pendidikan karakter untuk mewujudkan bangsa yang berdaulat di bidang politik, berdaulat di bidang ekonomi, dan berkepribadian di bidang budaya (Esthu, 2010). Trisakti oleh Soekarno disebut sebagai survival theory (Esthu, 2010), yang bahwa kita semua haruslah mengabdi kepada kepentingan rakyat banyak, mengabdi kepada kepentingan umum, dan mengabdi kepada bangsa dan negara. Asas kekeluargaan menjadi dasar membangun karakter bangsa sebab keluarga adalah meja statis dan leitstar dinamis. Di dalam keluarga itu akan tertanam semangat dan cita-cita berbangsa yang dalam Pembukan UUD 1945 dapat diringkas sebagai: “...supaya berkehidupan berkebangsaan yang bebas, ...yang merdeka, bersatu, berdaulat, adil dan makmur,” (Esthu, 2013).

Presiden Clinton dan kemudian presiden Bush menyatakan bahwa setiap tahun pada minggu ketiga bulan Oktober menjadi minggu Karakter Nasional. Secara tegas George W. Bush, presiden Amerika Serikat (charactercounts, n.d.) mengatakan: "Berdasarkan wewenang yang diberikan kepada saya oleh Konstitusi dan hukum negara Amerika, dengan ini menyatakan 16 Oktober sampai 22 Desember 2005, sebagai hari-hari Pendidikan Karakter Nasional. Saya menyerukan kepada pejabat publik, pendidik, pustakawan, orangtua, siswa, dan semua orang Amerika untuk mengamati hari-hari tersebut dalam upacara, kegiatan, dan program-program negara lainnya.”

Megawangi (2007) menyebutkan bahwa Pendidikan Karakter sebagai solusi dalam menjawab permasalahan negeri ini. Pendidikan karakter tidak hanya mendorong pembentukan perilaku positif anak, tetapi juga meningkatkan kualitas kognitifnya. Pengembangan karakter atau character building membutuhkan partisipasi dan sekaligus merupakan tanggung jawab dari orangtua, masyarakat, dan pemerintah. Sebab dengan menjadi dewasa secara rohani dan jasmani, seseorang menjadi berkepribadian yang bijaksana baik terhadap dirinya sendiri, keluarga, dan masyarakat. (Illiyun, 2012)

Para pakar di Balitbang Pusat Kurikulum Kemendikbud berhasil menginvetarisasi 18 karakter yang harus menjadi acuan para pendidikan secara nasional (Satriwan, 2012). Nilai-nilai yang dikembangkan dalam pendidikan budaya dan karakter bangsa bersumber dari nilai-nilai Agama, Pancasila, Budaya dan Tujuan Pendidikan Nasional, yang kemudian diidentifikasi menjadi 18 karakter bangsa: religius, jujur, toleransi, disiplin, kerja keras, kreatif, mandiri, demokratis, rasa ingin tahu, 
semangat kebangsaan, cinta tanah air, menghargai prestasi, bersahabat/komunikatif, cinta damai, gemar membaca, peduli lingkungan, peduli sosial dan tanggung jawab (Satriwan, 2012).

Berdasarkan hal-hal yang telah dikemukakan, rumusan masalah dalam penelitian ini adalah tentang pentingnya Pendidikan Karakter dalam meningkatkan individu, keluarga, dan masyarakat dalam mencapai kebahagiaan. Sementara tujuan penelitian adalah mencari data dalam masyarakat untuk membuktikan seberapa penting Pendidikan Karakter berdampak terhadap kebahagiaan individu, keluarga, dan masyarakat.

\section{METODE}

Metode yang digunakan dalam penelitian ini adalah grounded research untuk memperoleh dan menganalisis data tentang pengaruh Pendidikan Karakter terhadap kebahagiaan individu, keluarga, dan/atau masyarakat. Untuk itu didesain 2 strategi penelitian, yaitu (1) pengaruh Pendidikan Karakter terhadap kebahagiaan individu dan (2) pengaruh Pendidikan Karakter terhadap kebahagiaan keluarga/masyarakat. Kedua desain strategi penelitian tersebut seperti terlihat pada Gambar 1 dan Gambar 2 berikut.

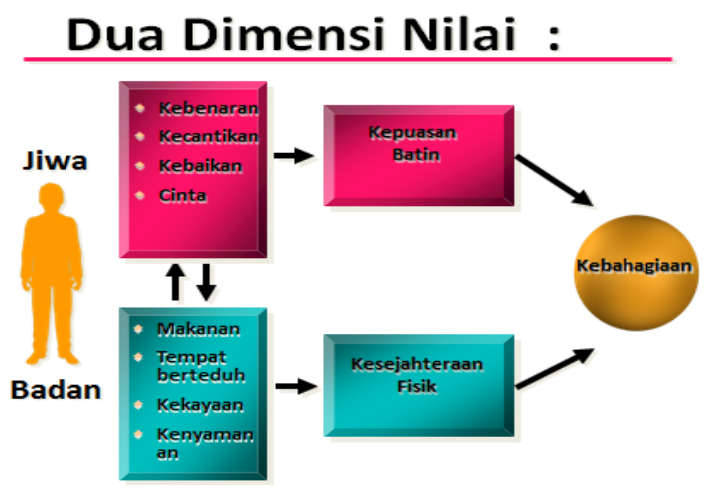

Gambar 1 Pengaruh Pendidikan Karakter terhadap Kebahagiaan Individu

\section{Dua Dimensi Pendidikan :}

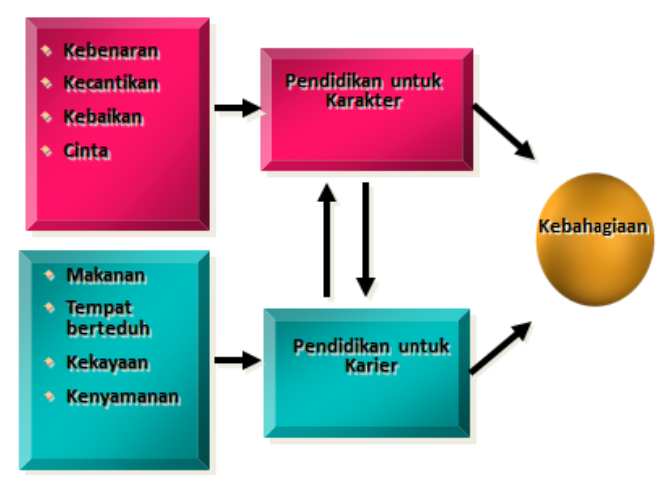

Gambar 2 Pengaruh Pendidikan Karakter terhadap Kebahagiaan Keluarga/Masyarakat

Subjek atau partisipan yang terlibat dalam grounded research ini adalah orang-orang yang dalam hidup kesehariannya mengalami dampak positif atau negatif terhadap Pendidikan Karakter. 
Orang-orang tersebut beberapa di antaranya ditemui secara pribadi dan beberapa lainnya menggunakan data skunder. Tahapan penelitian individu, keluarga, dan masyarakat berlangsung sekaligus secara simultan. Melalui tahapan ini diharapkan terjadi peningkatan kedasaran akan dampak positif Pendidikan Karakter terhadap kebahagian individu maupun keluarga dan masyarakat. Selanjutnya, melalui peningkatan kesadaran tersebut terbentuk komitmen untuk melaksanakan Pendidikan Karakter secara terus menerus, baik untuk individu maupun keluarga/masyarakat. Akhirnya, individu, keluarga, dan kelompok masyarakat khususnya Indonesia makin bahagia karena memiliki akhlak yang baik.

\section{HASIL DAN PEMBAHASAN}

Hasil dan pembahasan penelitian dikelompokkan menjadi 3 bagian besar yaitu (1) pengaruh Pendidikan Karakter terhadap kebahagiaan Individu, (2) pengaruh Pendidikan Karakter terhadap kebahagiaan keluarga, dan (3) pengaruh Pendidikan Karakter terhadap masyarakat/negara.

\section{Pengaruh Pendidikan Karakter terhadap Kebahagiaan Individu}

Mullins (2005) menegaskan hasil penelitiannya tentang neorologi bahwa setiap individu memiliki rasa alami tentang keadilan yang menembus persepsi sosial dan interaksi yang selalu digunakannya sebagai komponen dasar dalam pengambilan keputusan. Pengalaman moral memberi peran penting pada emosi yang memerankan nilai-nilai dalam peristiwa, benda, dan tindakan. Sektor orbital dan medial dari korteks prefrontal dan daerah sulcus superior temporal dalam otak manusia, yang merupakan daerah penting untuk perilaku sosial dan persepsi, memainkan peran sentral dalam penilaian moral. Kegiatan sosial dengan nilai-nilai moral dapat menjadi mekanisme penting dalam perilaku sosial setiap individu.

Secara alami setiap idividu telah mempunyai kepribadian asli. Namun dalam perkembangannya, lingkungan sangat memengaruhi kepribadian asli tersebut. Lingkungan yang memengaruhi tersebut dapat dilihat sebagai pengembangan karakter individu yang memengaruhinya menjadi lebih kuat, lebih lemah, atau mungkin justru tergantikan dengan karakter baru.

Kebahagiaan seseorang sesuai Gambar dipengaruhi oleh dua dimensi nilai, yaitu kepuasan batin dan kesejahteraan fisik. Kepuasan batin ditentukan oleh nilai kebenaran, kecantikan, kebaikan, dan cinta yang bersumber dari jiwa. Sedangkan kesejahteraan fisik ditentukan oleh makanan, tempat berteduh, kekayaan, dan kenyamanan yang bersumber dari badan. Dengan kata lain, kebahagiaan individu ditentukan oleh keseimbangan antara kepuasan batin dan kesejahteraan fisik seseorang.

\section{Pengaruh Pendidikan Karakter terhadap Kebahagiaan Keluarga}

Pengaruh keluarga juga dapat dilihat sebagai proses pendidikan. Pendidikan tidak hanya berorientasi pada penguasaan ilmu pengetahuan, tetapi juga diarahkan pada penanaman nilai-nilai yang akan membentuk karakter dan kepribadian seseorang. Hal itu disebabkan pendidikan tanpa dilandasi dengan karakter, tidak akan pernah memberikan sumbangan yang cukup berarti bagi komunitas. Pendidikan yang tidak mempertimbangkan pengembangan karakter akan menyengsarakan orang lain dan melukai rasa kemanusiaan. Ada banyak contoh kasus dalam kehidupan bermasyarakat, bagaimana pengetahuan yang tidak dilandasi akhlak-moral digunakan untuk membodohi banyak orang, hanya ditujukan demi kepentingan dan keuntungan pribadi. Sebagai contoh, beberapa anak sekolah dan juga warga terlibat dalam tawuran, penggunaan obat-obat terlarang, perampokan di bis kota, dan sebagainya. 
Jika ditelusuri lebih jauh, krisis dalam kehidupan berbangsa dan bernegara terkait banyak dengan kehidupan keluarga yang kurang harmonis dalam masyarakat (Ngamanken, 2011). Banyak keluarga mengalami kehilangan arah tidak hanya karena menghadapi krisis ekonomi, tetapi juga karena faktor globalisasi nilai-nilai dan gaya hidup yang tidak selalu searah dengan nilai-nilai dan norma-norma agama serta budaya yang ada di Indonesia. Sebagai contoh, gaya hidup hedonistis dan materialistis, dan permisif sebagaimana banyak ditayangkan dalam telenovela dan sinetron di berbagai saluran TV Indonesia hanya mempercepat disorientasi dan dislokasi keluarga dan rumah tangga. Kebahagiaan keluarga sesuai Gambar 2 dipengaruhi dua dimensi pendidikan, yaitu pendidikan untuk karakter dan pendidikan untuk karier. Pendidikan untuk karakter berorientasi kepada penguasaan ilmuilmu tertentu untuk memperoleh pekerjaan yang baik atau karier. Sedangkan pendidikan untuk karakter berorientasi kepada pembentukan karakter yang baik. Dengan kata lain, kebahagiaan keluarga ditentukan oleh keseimbangan antara pendidikan karier dan pendidikan karakter semua anggota keluarga.

\section{Pengaruh Pendidikan Karakter terhadap Kebahagiaan Masyarakat/Negara}

Mempertimbangkan berbagai kenyataan yang telah dikedepankan pada poin 1 dan 2 tersebut dapat disimpulkan bahwa Pendidikan Karakter merupakan langkah penting dan strategis dalam mengembangkan terus menerus jati diri bangsa dan menggalang pembentukan masyarakat Indonesia yang bahagia.

Pendidikan Karakter merupakan tanggung jawab individu, keluarga, dan masyarakat sebagai pihak yang akan memperoleh kebahagiaan bersama sebagai hasilnya. Dari ketiga pihak tersebut, keluarga adalah pihak pertama dan utama dalam pendidikan karakter pertama dan utama. Keluarga harus menjadi sekolah cinta kasih (Ngamanken 2011).

Pihak kedua adalah sekolah. Pendidikan karakter perlu ditingkatkan melalui proses belajar mengajar di sekolah. Sekolah tidak hanya bertanggung jawab untuk mencetak peserta didik yang unggul dalam ilmu pengetahuan dan teknologi, tetapi juga dalam jati diri, karakter, dan kepribadian.

Pihak ketiga adalah masyarakat. Melaui peningkatan pendidikan karakter melalui contoh pengalaman hidup sehari-hari yang baik di masyarakata dapat memperkokoh jati diri dan ketahanan masyarakat Indonesia yang multikultural, yang memiliki beragam budaya. Keragaman budaya merupakan salah satu kekayaan bangsa Indonesia yang tidak dimiliki bangsa lain. Bahkan secara konstitusional, baik dalam UUD 1945, Pancasila maupun dalam prinsip negara bhinneka tunggal ika, keragaman budaya itu sudah memperoleh landasan yang kuat.

Pengakuan terhadap keragaman budaya hampir sama dengan prinsip multikulturalisme, yang berdasar pada politik pengakuan (politics of recognition), mengakui setiap warga memiliki posisi yang setara satu sama lain. Tidak kurang pentingnya, pengakuan terhadap keragaman itu didasarkan pada prinsip saling menghormati dan menghargai di tengah berbagai perbedaan yang ada.

\section{SIMPULAN}

Kebahagiaan individu tercapai jika ada keseimbangan antara dimensi nilai kepuasan batin dan kesejahteraan fisik. Kebahagiaan keluarga tercapai jika ada keseimbangan antara pendidikan untuk karier dengan pendidikan untuk karakter. Individu-individu dalam suatu keluarga sangat menentukan bahagia tidaknya keluarga tersebut, yang berlatar dari pendidikan karakter mereka masing-masing. Demikian juga keluarga-keluarga dalam suatu komunitas, termasuk komunitas negara, sangat menentukan bahagia tidaknya komunitas tersebut, yang berlatar dari kebahagiaan keluarga-keluarga 
dalam komunitas tersebut. Dengan demikian pendidikan karakter merupakan langkah penting dan strategis dalam mengembangkan terus menerus jati diri bangsa dan menggalang pembentukan masyarakat Indonesia yang bahagia.

Individu, keluarga dan masyarakat adalah tiga pihak yang perlu bekerja sama dalam pengembangan pendidikan karakter. Indonesia sebagai suatu komunitas perlu memiliki wawasan kebangsaan yang ditanamkan melalui pendidikan katakter. Pendidikan karakter yang selama ini dilakukan di sekolah, masyarakat, dan pendidikan formal perlu lebih ditingkatkan untuk mengarah kepada internalisasi nilai-nilai dalam rangka pembentukan akhlak demi kebahagiaan individu, keluarga, dan masyarakat Indonesia.

\section{DAFTAR PUSTAKA}

Esthu, G. S. (2010, 20 Agustus). Membangun Karakter Bangsa. Diakses 25 Februari 2013 dari http://edukasi.kompasiana.com/2010/08/20/membangun-karakter-bangsa- $\quad$ 233267.html

(2013, 10 Januari). Zaman Kalabendu. Diakses 25 Februari 2013 dari http://sosbud.kompasiana.com/2013/01/10/zaman-kalabendu-523078.html

Illiyun, N. N. (2012, 16 November). Pendidikan Karakter, Sebuah Agenda Perbaikan Moral Bangsa. Diakses 25 Pebruari 2013 dari http://generasibersih.0fees.net/?p=32

Koesoema, A. D. (2007). Pendidikan Karakter: Strategi Mendidika Anak di Zaman Global. Jakarta: Grasindo.

Megawangi, R. (2007). Semua Berawal pada Karakter. Jakarta: Lembaga Penerbitan FE-UI.

Mullins, A. (2005). Parenting for Character: Equipping Your Child for Life. Sydney: Finch Publishing.

Ngamanken, A. (2011). Family as the School of Love. International Conference on Character Building, Universitas Negri Jakarta, 25-26 November, 2011.

Satriwan. (2012, 15 Oktober). Pendidikan (Karakter) Salah Kaprah. Diakses dari http://edukasi.kompasiana.com/2012/10/15/pendidikan-karakter-salah-kaprah-501329.html 